\title{
Compacted black cotton soil treated with cement kiln dust as hydraulic barrier material
}

\author{
F.O.P. Oriola and G. Moses \\ Department of Civil Engineering, Nigerian Defense Academy, Kaduna, Nigeria.
}

\begin{abstract}
Laboratory tests were conducted on black cotton soil treated with up to $16 \%$ Cement Kiln Dust (CKD) by dry weight of soil to assess its suitability for use in waste containment application. Specimens were prepared at molding water contents $-2 \%, 0 \%,+2 \%$ and $+4 \%$ of the optimum moisture content at the compactive energy levels of British Standard Light (BSL) and West African Standard (WAS). Index properties, hydraulic conductivity (k), volumetric shrinkage strain (VSS) and unconfined compressive strength (UCS) tests were carried out. Results obtained showed slight changes in index properties. Hydraulic conductivity values recorded at both BSL and WAS produced satisfactory results that met the regulatory $1 \times 10^{-9} \mathrm{~m} / \mathrm{s}$ requirement at all treatment levels. The UCS values after 4\% CKD treatment especially at WAS compactive energy level met the minimum regulatory value of $200 \mathrm{kN} / \mathrm{m}^{2}$ for shear strength. VSS values recorded met the regulatory requirement of less than $4 \%$ volumetric shrinkage strain at $16 \%$ CKD content for BSL and 12 and 16\% CKD contents for WAS energy level. The overall acceptance zone for CKD treated black cotton soil was achieved at 12 and $16 \%$ cement kiln dust content for specimen prepared at molding water content range of $16.7-21.6 \%$ and $17.2-19.3 \%$ respectively.
\end{abstract}

Keywords: Acceptable zone, Cement Kiln Dust, Compaction, Durability, Hydraulic conductivity, Unconfined Compressive Strength, Volumetric Shrinkage Strain

\section{INTRODUCTION}

Compacted soil liners are normally used as an integral component of the lining system, to impede the transport of contaminants, to cover landfills, municipal and hazardous waste impoundments, and also to cap new or old waste disposal units (Daniel and Benson 1990; Benson 1999; Albrect and Benson 2001). Solid waste consist of materials, which are classified according to their physical and chemical properties as garbage, rubbish, trash, junks and ashes. (Hagerty et al, 1973). The feasibility, environmental suitability and performance of the beneficial reuse of industrial and agricultural waste material are increasingly being investigated by researchers. Some of these materials include plastics, glass, scrap tires, fly Ash, cement kiln dust etc.

Other materials used as liners or cover in waste containment systems. Includes natural clayey soils, includes, processed clay/sand-processed clay mixtures, Geosynthetic materials and industrial waste products. (Bowders et al, 1987; Frebrer 1996; Abichon et al, 2002; Albrecht and Benson, 2001). Furthermore, Studies have been carried on the use of compacted lateritic soil as liners and cover in waste containment application (Liman, 2009; Osinubi and
Nwaiwu, 2005, 2005a,b; Osinubi and Eberemu, 2006; Osinubi and Eberemu, 2009b; Osinubi and Amadi, 2006; Osinubi and Amadi, 2009, 2010; Amadi, 2006 and Eberemu, 2006). Lime had been used to stabilize the hydraulic conductivity of clay against chemical attack by organic solutions (Broderick and Daniel 1990), and as an additive to reduce the hydraulic conductivity of fly ash (Bowders and Daniel, 1987).

Cement kiln dust (CKD) is an industrial waste from cement production. The quantities and characteristics of CKD generated depend upon a number of operational factors and characteristics of the inputs to the manufacturing process. Although the relative constituent's concentrations in CKD can vary significantly, CKD has certain physical characteristics that are relatively consistent. When managed on site in a waste pile, CKD can retain these characteristics within the pile while developing an externally weathered crust, due to absorption of moisture and subsequent cementation of dust particles on the surface of the pile (Liman, 2009). The ability of the CKD to absorb water stems from its chemically dehydrated nature, which results from the thermal treatments it receives in the system. the action of absorbing water (rehydrating) releases a significant amount of heat from non-weathered crust, a 
phenomenon that can be exploited in beneficial reuse in order to improve the inadequacy of some avoidable extensive clay material for use waste containment facilities.

Expansive soils are also referred to as "black cotton soil" in some parts of the world. They are so named because of their suitability for growing cotton. Black cotton soils have colors ranging from light grey to dark grey and black. Black cotton soils are confined to the semi arid regions of tropical and temperate climatic zones and are abundant where the annual evaporation exceeds the precipitation (Chen, 1975; Waen and Kirly; 2004), Balogun (1991) reported that black cotton soils occur in continuous stretches as superficial deposits and are typical of flat terrains with poor drainage. The absence of quartz in the clay mineralogy enhances the formation of fine-grained soil material, which is impermeable and waterlogged.

Morin (1971) reported that the Lake Chad Basin is the only extensive lacustirne deposit of black cotton soil in Africa. The black cotton soils of North Eastern Nigeria were laid during the tertiary and quaternary periods of the Chad formation and are composed of a sequence of lacustrine and fluviatile clays and sands of Pleistocene age. These sediments (lacustrine sands, lagoonal clays, deltaic sands and clays, beach sands and gravels as well as aeolian sands) underlie the country North and East of Abakire and extend along the plains of Borno and Lake Chad and beyond (Ola, 1983). It was also reported that black cotton soils occupy an estimated area of $104 \times 10^{3} \mathrm{~km}^{2}$ in Northeastern Nigeria. The mineralogy of this soil is dominated by the presence of montimorillonite which is characterized by large volume change from wet to dry seasons and vice versa. Deposits of black cotton soil in the field show a general pattern of cracks during the day season of the year. Cracks measuring $70 \mathrm{~mm}$ wide and over $1 \mathrm{~m}$ deep have been observed and may extend up to $3 \mathrm{~m}$ or more in case of high deposit (Adeniji 1991).

Research work has been carried out on the improvement of geotechnical characteristics of black cotton soil with very little success using bagasse ash pozzolana ( Ijimdiya, 2009). However, no work has been done on the use of CKD treated black cotton soil in waste containment applications. The study was aimed at the evaluation of the suitability of compacted black cotton soil treated with CKD for use in waste containment applications; typical oxide composition of the cement kiln dust is shown in tables.1.

Table 1: Basic Properties and Typical Oxide Composition of the Cement kiln dust

\begin{tabular}{|l|l|l|l|l|l|l|l|l|l|}
\hline Oxide & $\mathrm{CaO}$ & $\mathrm{Al}_{2} \mathrm{O}_{3}$ & $\mathrm{SiO}_{2}$ & $\mathrm{Fe}_{2} \mathrm{O}_{3}$ & $\mathrm{Mn}_{2} \mathrm{O}_{3}$ & $\mathrm{Na}_{2} \mathrm{O}$ & $\mathrm{K}_{2} \mathrm{O}$ & $\mathrm{pH}$ & $\mathrm{Gs}$ \\
\hline Concentration (\%) & 50.81 & 4.71 & - & 1.92 & 0.002 & 0.001 & 1.35 & 11.2 & 2.22 \\
\hline
\end{tabular}

\section{MATERIALS AND METHODS}

\section{Materials:}

Black Cotton Soil: The soil used in this study is dark grey in colour and is known as black cotton soil, it was obtained along New-Marte road in Bayo Local Government Area of Borno State using the method of disturbed sampling. The location lies along (latitude $10^{\circ} 19^{\prime} \mathrm{N}$ and longitude $\left.11^{\circ} 30^{\prime} \mathrm{E}\right)$. Specimens were varied with $0,4,8,12$ and $16 \%$ of cement kiln dust by dry weight of soil.

Cement Kiln Dust: The cement kiln dust used was obtained from freshly deposited heaps of the waste at the Ashaka cement production plant located in Nafada Local Government Area of Gombe state, Nigeria. The CKD was sieved through Bs sieve No. 200 and was stored in air-tight containers before usage.

\section{Methods}

Index Properties: Laboratory tests were conducted to determine the index properties of the natural soil and soil - cement kiln dust mixtures in accordance with British Standards BS 1377 (1990) and BS 1924 (1990) respectively. A summary of the soil index properties is presented in Table 2 . 
Am. J. Sci. Ind. Res., 2011, 2(4): 521-530

Table 2: Engineering Properties of CKD Treated Black Cotton Soil

\begin{tabular}{|c|c|c|c|c|c|}
\hline \multirow[t]{2}{*}{ Engineering Properties } & \multicolumn{5}{|c|}{ Cement kiln dust (\%) } \\
\hline & 0 & 4 & 8 & 12 & 16 \\
\hline Liquid Limit, \% & 67.5 & 65.0 & 72.6 & 65.0 & 64.0 \\
\hline Plastic Limit, \% & 22.8 & 20.6 & 19.2 & 16.9 & 14.4 \\
\hline Plasticity Index, \% & 44.7 & 44.4 & 53.4 & 39.1 & 54.6 \\
\hline Linear Shrinkage, \% & 15.3 & 13.3 & 13.1 & 14.0 & 13.5 \\
\hline $\begin{array}{l}\text { Percentage Passing BS No. } 20 \\
\text { Sieve. }\end{array}$ & 85.0 & 83.0 & 85.0 & 81.0 & 83.0 \\
\hline & & & & & \\
\hline USCS Classification & A-7-6 & A-7-6 & A-7-6 & A-7-6 & A-7-6 \\
\hline Specific Gravity & $C L$ & $C L$ & $\mathrm{CL}$ & $C L$ & $\mathrm{CL}$ \\
\hline MDD Mg/m3 & 2.36 & 2.37 & 2.39 & 2.38 & 2.65 \\
\hline Standard Proctor & & & & & \\
\hline West African Standard & 1.300 & 1.458 & 1.520 & 1.586 & 1.512 \\
\hline OMC\% & 1.400 & 1.510 & 1.560 & 1.610 & 1.660 \\
\hline Standard Proctor & & & & & \\
\hline West African Standard & 24.0 & 23.2 & 22.7 & 18.8 & 17.6 \\
\hline pH Value & 21.0 & 20.6 & 20.3 & 17.6 & 15.3 \\
\hline Color & 7.2 & - & & - & - \\
\hline Dominant Clay mineral & Dark Gray & & & & \\
\hline & Montimorillonite & & & & \\
\hline
\end{tabular}

Compaction: The compactive energy level used is the British Standard Light (BSL) and West African Standard (WAS). The tests involving moisture density relationship, volumetric shrinkage, unconfined compressive strength (UCS), and hydraulic conductivity. Air dried soil samples passing through BS sieve with $4.76 \mathrm{~mm}$ aperture mixed with $0 \%, 4 \%$, $8 \%, 12 \%$ and $16 \%$ cement kiln dust by weight of dry soil were used. The British standard light is the effort derived from $2.5 \mathrm{~kg}$ rammer falling through $30 \mathrm{~cm}$ onto three layers, each receiving 27 uniformly distributed blows; (BS 1990) The West African standard compactive effort (WAS), carried out using energies derived from a rammer of $4.5 \mathrm{~kg}$ mass falling through a height of $45 \mathrm{~cm}$ in a $1000 \mathrm{~cm}^{3}$ mould. The soil was compacted in five layers, each layer receiving 10 blows.

Hydraulic Conductivity: This was measured using the rigid wall permeameter under falling head condition as recommended by Head (1992). A relatively short sample was connected to a standpipe, which provided the head of water flowing through the sample. Compacted soil - CKD samples at the different CKD contents (0\%, 4\%, 8\%, 12\% and 16\%) and different molding water contents $(-2 \%, 0 \%,+2 \%$ and $+4 \%$ of the OMC, respectively) using the BSL and WAS compactive efforts. Specimens were soaked in a water tank for a minimum period of 24 hours to allow for full saturation and the samples were restrained from swelling vertically during saturation. The fully saturated test specimen was 
then connected to a permeant liquid (tap water). During permeation, test specimens were free to swell vertically (i.e., no vertical stress was applied). Hydraulic gradient ranged from 5 to 15.Test were only discontinued when hydraulic conductivity readings were steady.

Unconfined Compressive Strength: This test was carried out in accordance with British Standards (BS 1990). Unconfined compressive strength (UCS) test were performed on cylindrical specimens $38.1 \mathrm{~mm}$ in diameter and length of $76.2 \mathrm{~mm}$. This ensured testing of soil specimens with length to diameter ratio of 2 . Air dried soil - CKD mixtures were compacted at $2 \%, 0 \%,+2 \%$ and $+4 \%$ of the optimum moisture content (OMC) and maximum dry density of the BSL and $W$ AS energy levels. After each compaction, the soil was extruded from the mould and sealed in polythene bag to minimize moisture loss, and kept for a period of 48 hours to allow for uniform moisture distribution and curing, at a constant temperature of $25 \pm 2^{\circ} \mathrm{C}$. After curing specimens they were placed in a load frame UCS machine driven strain controlled at $0.10 \% / \mathrm{min}$ until failure occurred. Three specimens were averagely prepared for each test.

Volumetric Shrinkage: The volumetric shrinkage upon drying was measured by extruding cylindrical specimens, compacted using the BSL and WAS energy levels. Air dried soil - CKD mixtures were compacted at $-2 \%, 0 \%,+2 \%$ and $+4 \%$ of the optimum moisture content (OMC). The extruded cylindrical specimens were placed on a laboratory bench at a uniform temperature of $29 \pm 2^{\circ} \mathrm{C}$ for 30 days to dry naturally. This method is considered to be better than the method used by Daniel and Wu (1993) in which compacted cylindrical specimens were made dry in an air-conditioned building. This is because natural drying in the laboratory is considered to duplicate field conditions. Measurements of diameters and heights for each specimen were taken with the aid of a vernier caliper accurate to $0.05 \mathrm{~mm}$. The average diameters and heights were used to compute the volumetric shrinkage strain.

\section{RESULTS AND DISCUSSION}

Index Properties: Results of tests carried out on the natural soil are summarized in Table.1. The soil is classified under the $A-7-6$ subgroup of the AASHTO classification system. Liquid limit and plasticity index values of $67.5 \%$ and $44.7 \%$, respectively, suggest that the soil is highly plastic. Thus, from the results obtained, the soil falls below the standard recommended for most geotechnical works (Butcher and Sailie, 1984).

Maximum Dry Density: The MDD for the BSL and WAS compactive effort is in conformity with the trend of decreasing OMC with increasing MDD. This is as a result of CKD occupying the void within the soil matrix and in addition, the flocculation and agglomeration of the clay particle due to exchange of ions (Osinubi, 2000 a; Moses, 2008; Oriola and Moses, 2010). While the final decrease in MDD for BSL compactive effort can be attributed to CKD, a low specific gravity material replacing the soil material which has a high specific gravity (Osinubi and Stephen 2007).

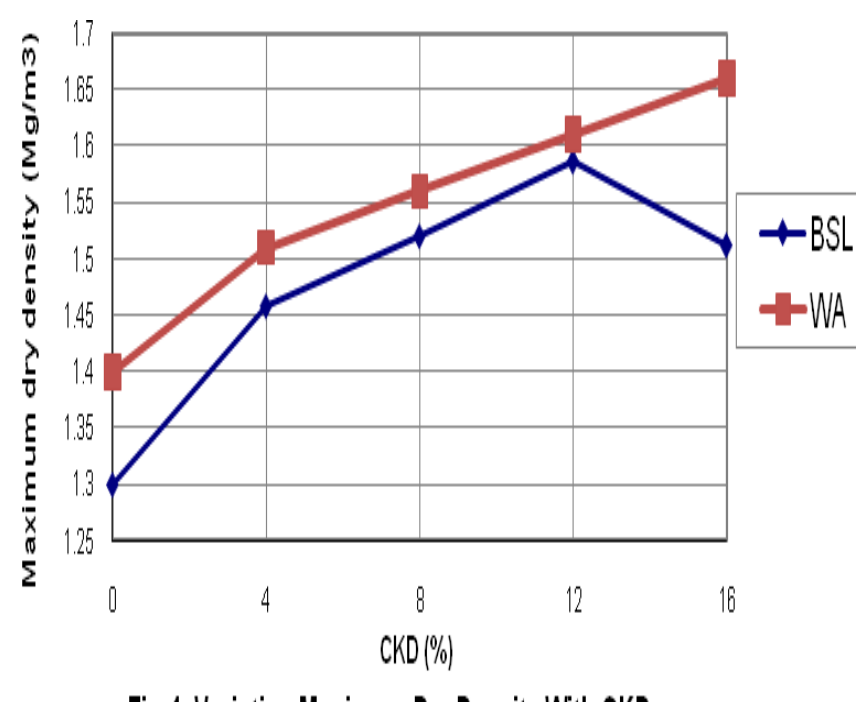

Fig.1:Variation Maximum Dry Density With CKD

Optimum Moisture Content: For specimens compacted at the British standard light and West African Standard energy levels, a decrease in OMC was recorded this is probably due to self desiccation in which all the water was used, resulting in low hydration. When no water movement to or from cement - paste is permitted, the water is used up in the hydration reaction, until too little is left to saturate the solid surfaces and hence the relative humidity within the paste decreases. The process described above might have affected the reaction mechanism of CKD treated black cotton soil (Osinubi and Stephen 2007, Moses 2008). 


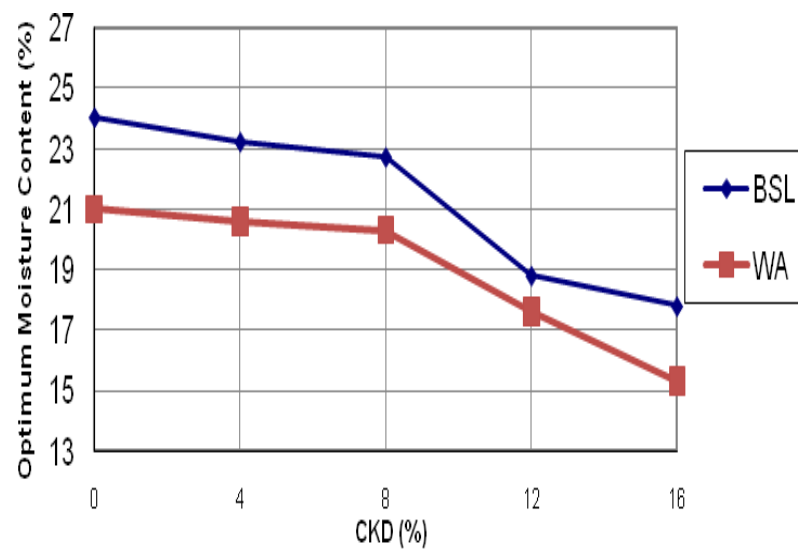

Fig.2 Variation of Optimum Moisture Content With CKD

Hydraulic Conductivity: Hydraulic conductivity is the key parameter affecting performance of liners and cover (Daniel 1987, 1990). The relationship between hydraulic conductivity and molding water content is shown in Fig.3. Generally the hydraulic conductivity obtained its lowest value on the wet side of compaction, especially at $+2 \%$ OMC for most of the specimen. Beyond +2 ' OMC and before $+2 \%$ OMC there is generally an increase in hydraulic conductivity values. The increasing molding water content facilitates deflocculating of the particle structure, reducing the void. This is in conformity with other research works (Lambe, 1959; Mitchell et al., 1965; Acer and Oliver; 1989, Garcia - Bengochea et al,. 1979; Benson and Daniel, 1990; Osinubi and Nwaiwu, 2006). Increasing molding water content from the dry to the wet side affects the hydraulic conductivity.

The variations of hydraulic conductivity with water content as shown in Fig.3, The result obtained for the untreated black cotton sample compacted between -2 to $+4 \%$ OMC. British Standard light and West African standard gave satisfactory hydraulic conductivity values less than $1 \times 10^{-9} \mathrm{~m} / \mathrm{s}$ (Benson and Daniel, 1990; Eberemu 2007 and Osinubi and Nwaiwu, 2006; Osinubi and Eberemu, 2009b). These minimum specified values were obtained at molding water contents of $23.3-29 \%$ and $19-25 \%$ respectively. The maximum permissible values were obtained at $25.1 \%$ and $23 \%$ molding water contents respectively.

At 4\% CKD treatment satisfactory hydraulic conductivity were obtained values indicating that CKD has filled the air voids present in the black cotton. The molding water contents of $21.2-27.2 \%$, at BSL and molding water content of $18.6-24.6 \%$ at WA energy level.

Furthermore, at $8 \%$ and $12 \%$ CKD treatments satisfactory hydraulic conductivity values were obtained. Above the 12\% CKD treatment insignificant molding water range was obtained for WA energy level. This could be as a result of the CKD displacing the clay contents \& fines in the specimen, thus making specimen incapable of satisfying the hydraulic conductivity specification values based on researches which have specify minimum clay content of $15 \%$ \& $30 \%$ fines (Daniel, 1993b; Benson et. al., 1994) for specimens of soil samples that will yield acceptable hydraulic conductivity values; (Benson et.al. 1994). Generally higher compactive efforts yield better results which are consistent other research works (Eberemu, 2007; Osinubi and Nwaiwu, 2006; Osinubi and Eberemu, 2009b.).

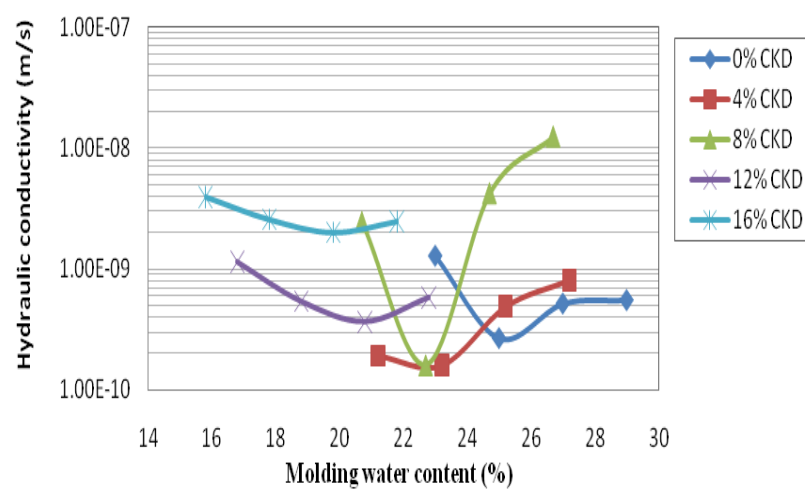

Fig.3: Variation of hy draulic conductivity with molding water content at BSL compactive effort

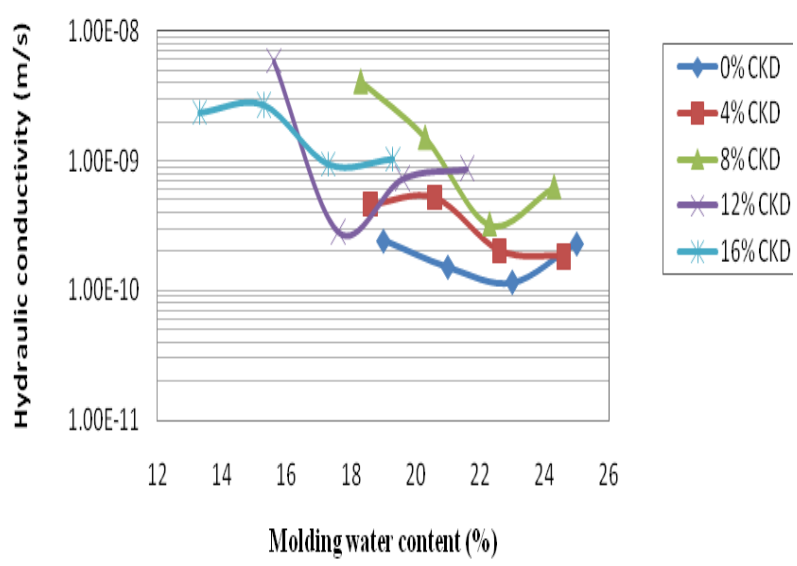

Fig.t: Variation of hydraulic conductivity with molding water content at WAS compactive effort 
Am. J. Sci. Ind. Res., 2011, 2(4): 521-530

Volumetric Shrinkage Strain: Researchers such as Daniel and Wu (1993), Tay et al.(2001) suggested that cracking do not likely occur in soil liners when compacted cylinders of the same soil undergo less than about $4 \%$ volumetric shrinkage strain (VSS) upon drying. The (VSS) showed great variation with molding water content as shown in Fig. 5-6. Generally as the CKD content increased for each energy level there is a decline in the volumetric shrinkage strain. Specimen compacted at greater moulding water content shrank more during drying which is consistent with the results of Daniel and Wu (1993), Albereachet and Benson (2001). The reasons for this is not farfetched because dry shrinkage in fine grained soils according to Mitchell (1976) depends on particle movement as a result of pore water tension developed by capillary menisci;

The specimen compacted between $-2 \%$ to $+4 \%$ of the OMC failed to produced satisfactory results up to $12 \%$ CKD treatment at BSL compactive effort. However, at $16 \%$ CKD and molding water content of 15.8-17.9\% an acceptable result was achieved for BSL compactive effort. Specimens compacted between $-2 \%$ to $+4 \%$ of the OMC for WAS compactive effort produced satisfactory VSS values at CKD treatment content of 12 and 16\%. These satisfactory VSS limiting values were attained at molding water contents of $15.6-21.6 \%$ and $13.3-$ $19.3 \%$ respectively. Generally, a decrease in the volumetric shrinkage strain was observed with increasing CKD treatments for both BSL and WAS energy levels; this can be attributed to the pozzolanic input of the CKD which reduces the fine grained soils. Coarser fractions of soils are formed due to the formation of bonds and thus VSS values are reduced (Liman, 2009). Furthermore, a decline in the volumetric strain is observed at $\mathrm{OMC}$ with increasing CKD content. This is largely attributed to the pozzolanic input of the pozzolana (Osinubi and Steven, 2007; Liman, 2009; Osinubi and Eberemu, 2009b).

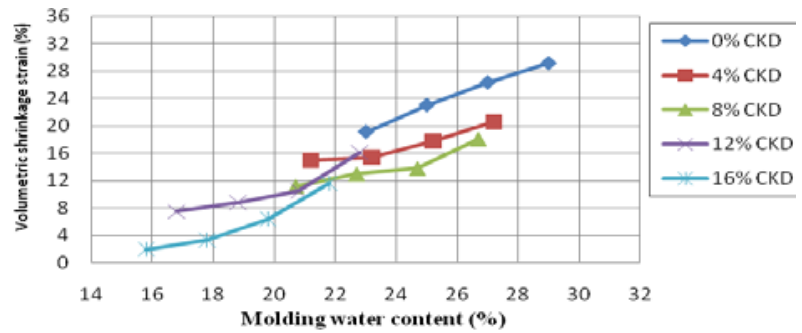

Fig.5: Variation of volumetric shrinkage strain with molding water content at BSL compactive effort

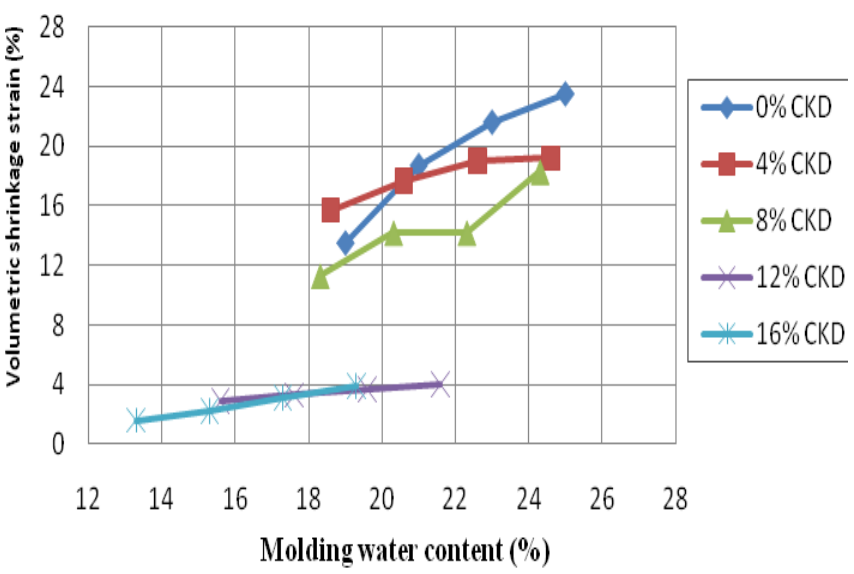

Fig.6: Variation of volumetric shrinkage strain with molding water content at WAS compactive effort

Unconfined Compressive Strength: The variations of unconfined compression test values with water content are shown in Fig.7-8. Daniel and Wu (1993) arbitrarily selected a minimum of $200 \mathrm{kN} / \mathrm{m}^{2}$ to support the maximum bearing stress in a landfill even though, the minimum required strength of soil to be used in compacted soil liners is not specified. The strength of the untreated black cotton soil decreases with increasing molding water content. As the molding water content increases electrolyte concentration is reduced, leading to an increased diffused double layer expansion and the distance between clay particles as well as the distance between the alumina-silicate unit layers increases, resulting in a reduction of both the internal friction and cohesion (Seed and Chanlasa; Daniel and Wu 1993 Taha and Kabir 2003, Taha and Kabir 2005; Nwaiwu, 2004; Osinubi et al., 2006a). However, treated samples recorded slight variations due to the fact that for any pozzolana there is an optimum mix of water to produce maximum strength as has been observed by previous researchers (Osinubi et al., 2007a; Osinubi et al., 2008)

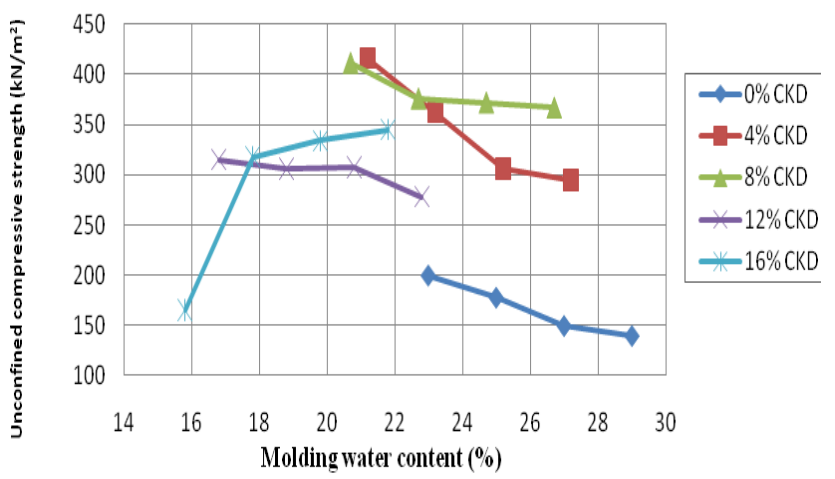

Fig.7: Variation of unconfined compressive strength with molding water content at BSL compactive effort 


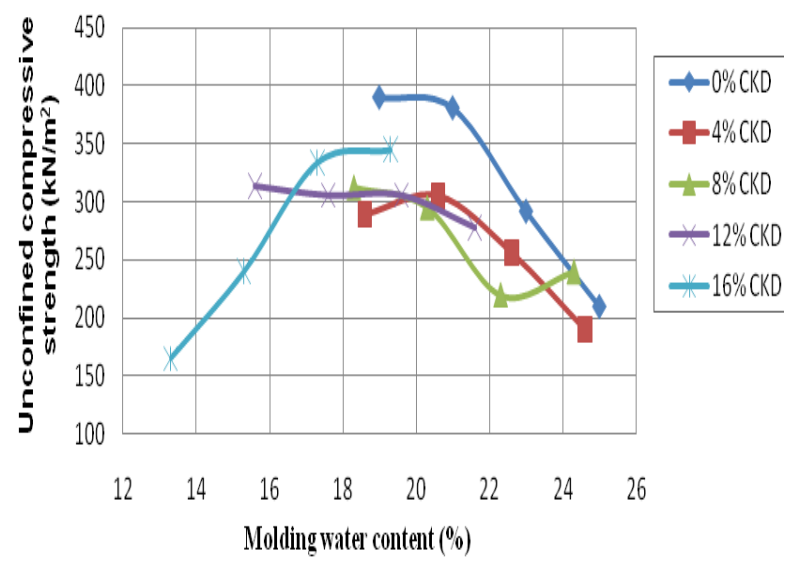

Fig.8: Variation of unconfined compressive strength with molding water content at WAS compactive effort

The minimum UCS value specified by Daniel and $\mathrm{Wu},(1993)$ were not satisfied for the untreated black cotton soil. The trend of the untreated black cotton soil is consistent with other research work on soils (Daniel and Wu, 1993; Tahar and Kabir, 2003; Osinubi and Nwaiwu, 2006; ljimdiya, 2009).

Above 0\% CKD treatment specimens met the minimum requirement for UCS value of $200 \mathrm{kN} / \mathrm{m}^{2}$ (Daniel and Wu 1993). However for samples treated at $16 \%$ CKD for both energy levels, slight deviations in pattern were observed, such that on the dry side of optimum, specimens failed to satisfy the minimum specified UCS value. This trend is similar to those reported by Eberemu (2007). This behavior is attributed to the incomplete hydration reaction of the pozzolana as a result of insufficient water.

Acceptable Zones: Liners and covers design involves the satisfaction of several parameters: hydraulic conductivity; shear strength, and; volumetric shrinkage stain. Daniel and Benson (1990), developed a relationship between the dry density and molding water content that will satisfy the three parameters. For the hydration conductivity the acceptable limit was set at less or equal to $1 \times 10^{-9}$ $\mathrm{m} / \mathrm{s}$, the volumetric shrinkage strain was set at a value of less or equal to $4 \%$ and the unconfined compressive strength value is set at $200 \mathrm{kN} / \mathrm{m}^{2}$ or more the compaction plane was arrived at by using the average shrinkage strain test specimens. Finally, after an acceptable zone for each of the parameters has been established at each CKD treatment by superimposing the various acceptance zone of each of the parameter, an overall acceptance zone is determined from the various acceptance zone of each of the individual parameter to produce an overall acceptance zone that covers all the specification requirements of the three individual parameters. The acceptable ranges for BSL and WAS energy levels have been presented in table 3 and 4

Table 3: Acceptable ranges of molding water contents at BSL energy level

\begin{tabular}{|c|c|c|c|c|c|}
\hline \multirow{3}{*}{$\begin{array}{l}\text { Engineering } \\
\text { Criteria }\end{array}$} & \multicolumn{5}{|c|}{ Cement Kiln Dust Content, \% } \\
\hline & 0 & 4 & 8 & 12 & 16 \\
\hline & \multicolumn{5}{|c|}{ Molding Water Content Range, \% } \\
\hline $\mathrm{k}, \mathrm{m} / \mathrm{s}$ & $\begin{array}{l}23.3- \\
29.0\end{array}$ & $\begin{array}{l}21.2- \\
27.2\end{array}$ & $21.3-24$ & $\begin{array}{l}17- \\
22.8\end{array}$ & $\begin{array}{l}17.1- \\
19.1\end{array}$ \\
\hline UCS, $\mathrm{kN} / \mathrm{m}^{2}$ & & $\begin{array}{l}21.2- \\
27.2\end{array}$ & $\begin{array}{l}20.7- \\
26.7\end{array}$ & $\begin{array}{l}16.8- \\
22.8\end{array}$ & $\begin{array}{l}16.5- \\
21.8\end{array}$ \\
\hline VSS, \% & & & & & $\begin{array}{l}15.8- \\
18.3\end{array}$ \\
\hline OAR & & & & & $\begin{array}{l}17.1- \\
18.3\end{array}$ \\
\hline
\end{tabular}

OAR - Overall Acceptable Range

Table 4: Acceptable ranges of molding water contents at WAS energy level

\begin{tabular}{|l|c|c|c|c|c|}
\hline \multirow{2}{*}{$\begin{array}{l}\text { Engineering } \\
\text { Criteria }\end{array}$} & \multicolumn{5}{|c|}{ Cement Kiln Dust Content, \% } \\
\cline { 2 - 6 } & $\mathbf{0}$ & $\mathbf{4}$ & $\mathbf{8}$ & $\mathbf{1 2}$ & $\mathbf{1 6}$ \\
\cline { 2 - 6 } & \multicolumn{5}{|c|}{ Molding Water Content Range, \% } \\
\hline $\mathrm{k}, \mathrm{m} / \mathrm{s}$ & $19.0-$ & $\begin{array}{l}18.6- \\
24.6\end{array}$ & $\begin{array}{l}21.0- \\
24.3\end{array}$ & $\begin{array}{l}16.7- \\
21.6\end{array}$ & $\begin{array}{l}17.2- \\
19.2\end{array}$ \\
\hline UCS, kN/m ${ }^{2}$ & $19.0-$ & $18.6-$ & $\begin{array}{l}18.3- \\
24.3\end{array}$ & $\begin{array}{l}15.6- \\
21.6\end{array}$ & $\begin{array}{l}14.4- \\
19.3\end{array}$ \\
\hline VSS, \% & 25.0 & 24.3 & 24.3 & $15.6-$ & $13.3-$ \\
& & & & 21.6 & 19.3 \\
\hline OAR & & & & $16.7-$ & $17.2-$ \\
& & & & 21.6 & 19.2 \\
\hline
\end{tabular}

OAR - Overall Acceptable Range

Overall acceptable zone: The design of liners and cover in waste containment facility involves arriving at a convergence of molding water content of three important design parameters. At this range of molding water content the regulatory specified values of the hydraulic conductivity, unconfined compressive strength and volumetric strain shrinkage must be met. Thus, an overall acceptance zone of molding water content and maximum dry density satisfactory for all the design parameters is produced (as shown in Fig.9 and 10). 
The satisfactory treatment level of CKD treated black cotton soil that gave an overall acceptance range for all the three established criteria were achieved at $12 \%$ CKD for BSL and 12\% and 16\% CKD. And they were achieved at a molding water content range of $16.7-21.6 \%$ and $17.2-19.2 \%$ respectively.
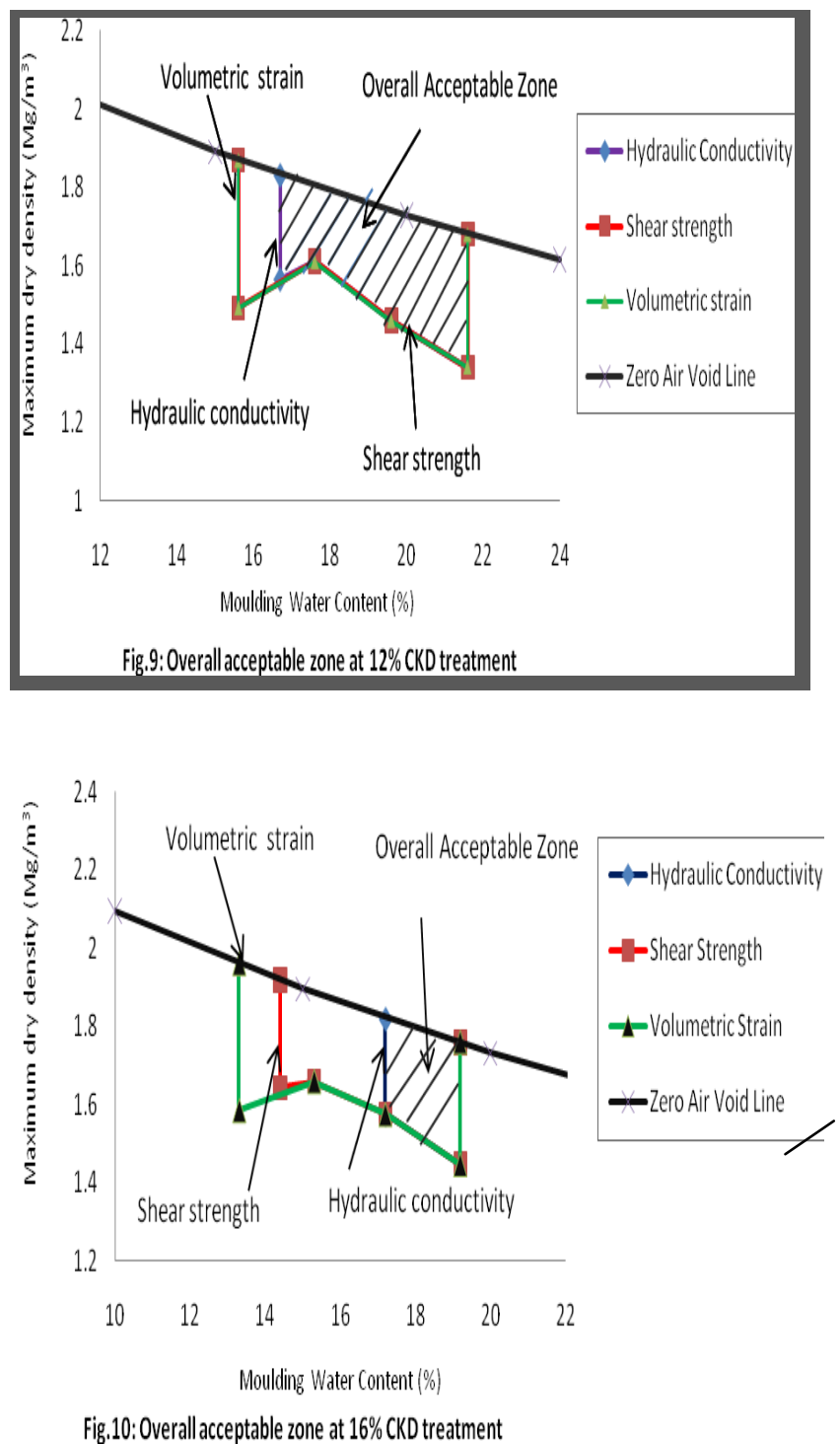

Conclusion and recommendation: The suitability of cement kiln dust for treatment of black cotton soil in waste containment facility produced successful results. There were changes in the index properties of the cement kiln dust treated black cotton soil specimen. However, the MDD generally increased with increasing CKD content while the OMC decreased with increasing CKD content.
Specimens were compacted at $-2 \%, 0 \%+2 \%$ and $+4 \%$ of the optimum moisture content at the energy levels of British standard light and West African standard compactive effort. in other to determine a suitable acceptance zone for the three important parameters (Hydraulic conductivity, Unconfined compressive strength and volumetric shrinkage strain). An assessment to produce a converging MDD and OMC that will produce covers and liner that meets the specification requirements of widely accepted standards of the three important parameters were designed. Hydraulic conductivity produced acceptable results at both BSL and WAS compactive efforts. Generally, a decline of hydraulic conductivity with increasing molding water content and increasing compactive energy level were observed.

For the UCS, the result show a general improvement in strength for up to $16 \%$ CKD treatment this is largely as a result of the pozzolanic input of CKD which produced stronger bonds. Treated black cotton soil produced improved volumetric shrinkage strain values at both BSL and WAS compactive efforts. But regulatory minimum VSS values were achieved only at $12 \%$ CKD for BSL, while $12 \%$ and 16\% CKD treatment produced successful results for WAS compactive effort.

Finally, the recommended overall acceptance zone that produced a convergence of the specification requirements of the three most important parameters for the design of liners and covers were achieved at $12 \%$ CKD and 16\% CKD treatment of black cotton soil at BSL and WAS compactive effort, and at molding water content ranges of $16.7-21.6 \%$ and 17.2-19.2 respectively.

\section{REFERENCES}

AASHTO (1986). Standard specification for transportation materials and methods of sampling and testing, $14^{\text {th }}$ Ed., Washington, D.C.

Abichou, T., Benson, C.H. and Edil, G. T. (2000). "Foundry green sand as hydraulic barriers laboratory studies." J. of Geotech. and Geoenvironmental Engrg. ASCE, Vol. 126. pp $1174-1183$

Abichou, T., Benson, C.H. and Edil, G. T. (2004). "Network model for hydraulic conductivity of sand bentonite mixture" Canadian Geotech Journal. 41 (4), 698 712.

Acar, Y. and Oliveri, I. (1989). "Pore fluid effects on the fabric and hydraulic conductivity of laboratory compacted clay." Transportation Research Record, Vol. 1219, pp. $144-159$. 
Adeniji F. A. (1991). "Recharge function of vertisolic vadose zone in sub-sahelian Chad Basin". Proc. Ist Inter. Conf. On Arid Zone Ideology Hydrology and Water Resources, Maiduguri, pp. $331-348$.

Albercht B. (1976). "Effect of dessication on compacted clay". M. Sc thesis, university of Wisconsin, Mdison, Wisconsin, U.S. A.

Albrecht, B. A. and Benson, C. (2001). "Effect of desiccation on compacted natural clay." J. Geotech and Geoenvir. Engrg., ASCE, Vol. 127, No. 1, pp. 67 75.

ASTM, (1992), Annual book of ASTM standards, Vol. 04. 08, Philadephia. Balogun, L. A. (1991). "Effect of sand and salt additives on some geotechnical properties of lime stabilized Black Cotton Soil". The Nigeria Engineer, 43(6), 669-681.

Chen, F. H. (1988). Foundations on Expansive Soils, Elsevier Scientific Pub. Co. Amsterdam.

Benson, C. H. and Daniel, D. E. (1990). "Influence of clods on hydraulic conductivity of compacted clay." J. Geotech. Engrg., ASCE Vol. 116, No. 8, pp. 1231 1248.

Benson, C.H. and Trast, J. (1995). " Hydraulic Conductivity of Thirteen Compacted Clay." J. geotech Eng'rg. ASCE Vol. 116,No.8, pp.1231 - 1248. .

Bowders, J. and Daniel, D. (1987). "Hydraulic conductivity of compacted clay to dilute organic chemicals." J. of Geotech. Engrg., Vol. 113. No. 12, pp. 1432-1448.

Boardman, B. T. and Daniel, D. E. (1996). "Hydraulic conductivity of desiccated goesyntehtic clay liners." J. of geotechnical eng'rg, vol. 122, no. 3, ASCE. Pp. $204-208$.

Broderick, G. and Daniel, D.E. (1990). "Stabilizing compacted clay against chemical attack." J. of Geotech. Engrg., ASCE, Vol. 116, No. 10, pp. 1549 $-1567$

BS 1377 (1990). Methods of Testing Soils for Civil Engineering Purposes. British Standard Institute, London.

BS 1924 (1990). Methods of Tests for Stabilized Soils. British Standard Institute, London.

Butcher, F.and Sailie, E. L., (1984). "Swelling behaviour of tropical black clays". Proc. Of the Eighth Reg. Conf. For Africa on Soil Mech. And Foundation Engineering, Harare, 81 - 86.

Daniel, D. E. (1993b). "Clay Liners", In Geotechnical Practice for Waste Disposal, (ed. David E. Daniel) Chapman \& Hall, London, UK, pp 137-163

Daniel, D. E. and Benson, C. H. (1990). "Water Content density criteria for compacted soil liners." J. Geotech. Engrg., ASCE, Vol. 166. No. 12, pp. 1811 - 1830.
Daniel, D. E. and Wu, Y. K. (1993). " Compacted clay liners and cones for arid site." J of geotech. Eng'rg. ASCE. Vol. 119, no. 2. pp. 223 - 237.

Eberemu, A. O. (2007). "Evaluation Compacted Lateritic Soil Treated With BagasseAsh as Hydraulic Barriers in Municipal Solid Waste Containment Systems" Unpublished PhD Thesis, Department of Civil Engineering, Ahmadu Bello University, Zaria.

Freber, B.W. (1996), "Beneficial reuse of selected foundry waste material." Proc .of $19^{\text {th }}$ International Madison Waste Conference, Madison, WI, No 13, Sept,, pp $246-257$.

Garcia_Bengochea, I., Lovell, and Altschaeffl, A. (1979). "Pore Distribution and Permeability of Silty Clays" J. Geotech. Engrg. ASCE, 105(7) pp. 839 - 856.

Head, K. H. (1992). Manual of Soil Laboratory Testing, Vol. 2. Permeability, Shear Strength and Compressibility Tests. Pentech Press, London.

Ijimdiya, S. (2009). "Evaluation Compacted Black Cotton Soil Treated With BagasseAsh as Hydraulic Barriers in Municipal Solid Waste Containment Systems." Unpublished PhD Thesis, Department of Civil Engineering, Ahmadu Bello Univesity, Zaria.

Lambe, T. W. (1958). "The structure of compacted clay" Journal of Soil Mechanics and Foundation Engineering Division, ASCE, Vol 84, No. 2, pp. 1 35.

Liman, A. (2009). "Evaluation Compacted Lateritic Soil Treated With Cement Kiln Dust as Hydraulic Barriers in Municipal Solid Waste Containment Systems." Unpublished MSc Thesis, Department of Civil Engineering, Ahmadu Bello Univesity, Zaria.

Moses, G. (2008) "stabilization of black cotton soil with ordinary portland cement Using Bagasse ash as admixture" IRJI Journal of Research in Engrg. Vol.5 No.3 , pp. 107-115

Oriola, F. and Moses, G. (2010). "Groundnut Shell Ash Stabilization of Black Cotton Soil" Electronic Journal of Geotechnical Engineering. Vol. 15, Bund, E 415428.

Mitchell, J. K. (1976). Fundamental of Soil Behaviour. John Wiley and Sons, Inc. Nicholson, P. G. and Kashyap, V. (1993). "Fly-ash stabilization of tropical Hawaiian soils." In: Fly Ash for Soil Improvement. Ed. By Kevan D. Sharp. Geot. Spec. Pub. No. 36, pp. $15-$ 29.

Nwaiwu, C. M.O. (2004). Evaluation of compacted lateritic solids as hydraulic barriers in municipal solid waste containment systems. Unpublished Ph.D Dissertation submitted to the department of Civil Engineering, Ahmadu Bello University, Zaria. 
Morin, W.J. (1971). "Properties of African tropical black clay soils".Proc $5^{\text {th }}$ Reg. Conf. For Africa on Soil Mech. and Found. Engineering, Luanda Angola, 1 - 9.

Ola, S. A. (1974). Need for Estimated Cement Requirement for Stabilization of Laterite Soils. J. Transp. Engrg. Div.,, ASCE, Vol. 100, No. 2, pp. 379 - 388.

Ola, S.A.(1983)."The geotechnical properties of black cotton soils of North Eastern Nigeria" In:

S.A. Ola(Editor). Tropical soils of Nigeria in Engineering Practice, A.A. Balkema,The Netherlands, Rotterdam,155-171.

Osinubi, K. J., and Amadi, A. A. (2010). 'Comparative assessment of contaminant sorption in

lateritc soil - bentonite mixtures.' Geoenvironmental Processes for Soil Remediation and Geohazard Mitigation, CD-ROM Geotechnical Special Publication No. 199, pp. 2779 - 2786.

Osinubi, K. J. and Amadi, A. A. (2009). "Hydraulic Performance of Compacted Lateritic Soil Bentonite Mixtures Permeated with Municippal Solid Waste Landfill Leachete." Transportation Reseach Board (TRB) 88 Annual Meeting CD-ROM 11-15 January, Washington DC, U.S.A. Subject. Geology and Earth Materials, Session APP40-Physico-Chemical and Biological Process in Soils Committe, Paper 4090620, pp 1-18.

Osinubi, K. J. and Eberemu, A. O. (2006). "Hydraulic conductivity of lateritic soils treated with blast furnace slag." Electronic Journal of Geotechnical Engineering. EJGE, Vol. 11. Bundle D, pp. 1-21.

Osinubi, K. J. and Nwaiwu, C. M. (2005). "Hydraulic conductivity of compacted lateritic soils." Journal of Geotechnical and Geoenvironmental Engineering, ASCE, Vol. 131, No. 8, pp. 1034 - 1041

Osinubi, K. J. and Nwaiwu, C. M. (2006). "Design of compacted lateritic soil liners and covers." Journal of Geotech and Geoenvironmental Engineering, ASCE Vol, No. 2, pp. $203-213$.

Osinubi, K. J. and Nwaiwu, C. M. O. (2009). "Desiccationinduced Shrinkage in Uncompacted Lateritic Soils." Journal of Geotechnical and Geological Engineering, GEGE, Spriger, Netherlands, Vol. 26, pp 603-611

Osinubi, K. J. and Ijimdya, T. S. (2008). 'Laboratory investigation of engineering use of bagasse ash.'
Nigerian Society of Engineers Technical Transactions, Vol. 43, No. 1, pp. 1-17.

Osinubi, K. J. and Eberemu, A. O. (2009a). "Compatibility and attenuative properties of laterite-blast furnace slag mixtures." Journal of Waste Technology and Management, Vol. 35, No. 1, pp. 7 - 16.

Osinubi, K. J., Eberemu, A. O. (2009b)."Desiccationinduced Shrinkage of Compacted Lateritic Soil treated with bagasse ash." The Twenty-Fourth International Conference on Solid Waste Technology and Management CD-ROM, 15-18 March, Philidelphia, PA, U.S.A. Session 5C: Bioreactors and Innovative Landfills, pp.856-867.

Osinubi, K.J. and Stephen, T.A. (2007). 'Influence of compactive efforts on bagasse ash treated black cotton soil.' Nigerian Journal of Soil and Environmental Research, Vol. 7, pp. 92-101

Shackelford, C. D. (1996). "Geotechnical design consideration for tailing dams". Proc. of the international Symposium on Seismic and Environmental Aspects of Dam Design; Earth, Concrete and Tailing Dams. Vol. I. Santiago, Chile, Oct. $14-18,1996$.

Seed, H.B., and Chan, C.K. (1959). "Structure and Strength Characteristic of Compacted Clays." J. of Soil Mechanics and Foundation Eng'rg, vol. 85, No.SM5, ASCE. Pp. $87-128$

Stewart. D.I., Cousens, T.W., Studds, P.G., and Tay. Y.Y. (1999). "Design parameters for bentonite-enhanced sand as a landfill liner." Proc. Inst. Civ. Eng., London. Geotech. Eng., 137. 187-195.

Taha, M.R., and Kabir, M.H (2005). "Assessment of Physical Properties of a Granite Residual Soil as an Isolation Barrier." Electronic Journal of Geotechnical Engineering. EJGE, vol 60, pp 263-274.

Warren, K.W. And Kirby, T.M. (2004) "Expansive Clay Soil A Wide Spread And Costly

Geohazard", Geostra, Geoinstitute Of The American Society Of Civil Engineers

Yoder, E. J. and Witczak, M. W. (1975). Principles of Pavement Design. John Wiley and Sons. Inc. New York, $300-321$ 